\title{
SINDROM RUANG KETIGA
}

\author{
Al-Muqsith ${ }^{1}$ \\ ${ }^{1}$ Bagian Anatomi Fakultas Kedokteran Universitas Malikussaleh,Lhokseumawe-Aceh 24352, Indonesia \\ *Corresponding Author: almuqsith@unimal.ac.id
}

\begin{abstract}
Abstrak
Sindrom ruang ketiga adalah saat cairan tubuh tidak terkumpul di dalam salah satu kompartemen tubuh (intrasel dan ekstrasel) dan akan berpindah ke dalam suatu ruangan tubuh (pleura, peritoneum, dan pericardial). Bila cairan berada di dalam sel, tubuh bisa menggunakannya untuk reaksi kimia. Bila cairan berada di kompartemen interstisial dan intravaskuler, tubuh dapat menggunakannya untuk pelumasan, reaksi kimia, dan bahan kimia bergerak dari satu tempat ke tempat lain. Cairan di ruang ketiga berada di luar sistem peredaran darah dan tidak bisa digunakan oleh tubuh. Hal ini dapat menyebabkan masalah serius seperti edema, penurunan curah jantung, dan hipotensi. Artikel ini ditulis agar dapat memberikan metode pengobatan untuk kondisi sindrom ruang ketiga, termasuk mengidentifikasi faktor yang merugikan, termasuk kondisi yang menyebabkan peningkatan permeabilitas pembuluh darah, kemampuan menghasilkan ruang ketiga. Juga termasuk mendiagnosis pasien dengan sindrom ruang ketiga, yang dapat mencakup ruang sepertiga dari cairan, material, atau keduanya. Pengobatan pasien tergantung pada penyebab, fase, dan faktor-faktor yang terlibat.
\end{abstract}

Kata kunci: Sindrom ruang ketiga; cairan tubuh; edema

\section{Third Space Sindrome}

\begin{abstract}
Third space sindrome is when body fluids collect somewhere that is not in one of the two compartments (intracell and extracell) where your body can use it and move to the other space (pleura, peritoneum, and pericardium). When fluids are inside cells, your body can use it for chemical reactions. When fluids are in the interstitial and intravascular compartments, your body can use it for lubrication, chemical reactions and moving chemicals from one place to another. Fluid in third spaces is outside of the circulatory system and cannot be used by the body. This can cause serious problems such as edema, decreased cardiac output, and hypotension. This article is written to know treatment method for third space syndrome condition, methods include prevention factors, including the condition of blood permeability, the ability to produce a third space. And also includes diagnosing patients with third space syndrome, which may include a third of the fluid, material, or second space. Treatment of third-spacing depends on the cause, the phase, and the factors involved.
\end{abstract}

Keywords: Third space sindrome; body fluids, oedema 


\section{PENDAHULUAN}

Air adalah komponen tubuh manusia yang paling banyak, rata-rata membentuk $60 \%$ berat tubuh, tetapi berkisar dari 40\% sampai $80 \%$. Kandungan air seseorang relatif tidak berubah, tetapi presentasi air tubuh bervariasi dari orang ke orang. Penyebabnya adalah varibialitas dalam jumlah lemak mereka. Air dalam tubuh tersebar antara dua kompartemen cairan utama yaitu cairan intraseluler (CIS) dan cairan ekstraseluler (CES). ${ }^{1}$ Kompartemen CIS membentuk sekitar dua pertiga dari air total tubuh (40\% dari berat badan). Sepertiga sisanya (20\% dari berat badan) dari air total tubuh yang terdapat di kompartemen CES dibagi menjadi plasma ( $5 \%$ berat badan) dan cairan interstitium ( $15 \%$ berat badan). ${ }^{1,2}$

Volume cairan, tekanan, serta kadar natrium dan albumin adalah kunci untuk menjaga keseimbangan cairan antara intraseluler dan ruang ekstraseluler (intravaskuler dan interstitial). Permeabilitas kapiler dan sistem limfatik juga berperan. Masalah dengan komponen ini dapat menyebabkan cairan bergeser dari ruang intravaskuler ke ruang interstitial. Beberapa kasus yang berkaitan dengan hal tersebut adalah: (a). Peningkatan volume cairan dapat disebabkan oleh penggantian cairan terlalu banyak atau disfungsi ginjal. Volume yang berlebihan dapat menyebabkan edema perifer, edema paru, disfungsi hati, edema serebral dan perubahan mental, dan penurunan curah jantung. Tanda-tanda lain dari kelebihan cairan termasuk distensi vena jugularis dan hipertensi; (b). Peningkatan tekanan kapiler hidrostatik sering menyertai gagal jantung. Gagal jantung kanan ditandai dengan peningkatan tekanan vena yang menyebabkan edema di hati dan pinggiran. Gagal jantung sisi kiri menyebabkan edema paru; (c). Hiponatremia, mungkin akibat dari kehilangan natrium; misalnya, kerugian gastrointestinal selama diare atau kehilangan cairan yang disebabkan oleh obat-obatan seperti diuretik. Hiponatremia juga dapat timbul dari volume yang overload. Juga disebut dilutional atau hiponatremia hipervolemi, ini dapat terjadi dengan penggantian cairan terlalu banyak, gagal jantung, sirosis hati, penyakit ginjal, hipotiroidisme, atau gangguan pengaturan vasopressin; (d). Kehilangan albumin mengganggu tekanan osmotik koloid. Protein plasma sangat penting untuk mempertahankan tekanan osmotik koloid. Albumin, konstituen protein utama dari ruang intravaskuler, menyumbang hingga 60\% dari total protein. Setiap kondisi yang menghancurkan jaringan atau mengurangi asupan protein dapat menyebabkan kehilangan protein dan ruang ketiga. Beberapa contoh adalah hipokalsemia, penurunan asupan zat besi, penyakit hati yang parah, alkoholisme, hipotiroidisme, malabsorpsi, malnutrisi, penyakit ginjal, diare, immobilitas, luka bakar, dan kanker; (e). Peningkatan permeabilitas kapiler hasil dari luka bakar dan bentuk lain dari trauma jaringan. Edema karena 
peningkatan permeabilitas kapiler dapat terjadi secara lokal, seperti dengan trauma lokal, atau secara sistemik seperti anafilaksis atau disseminated intravascular coagulation; (f). Obstruksi sistem limfatik umumnya disebabkan oleh penghancuran simpul getah bening untuk mengobati kanker. Sebuah obstruksi biasanya mengarah ke edema lokal; cairan dan plasma protein menumpuk dan tidak dapat mengalir ke sirkulasi umum karena obstruksi limfatik. Lymphedema pasca mastektomi adalah contoh dari jenis ruang ketiga. ${ }^{3}$

Cairan tubuh normalnya berpindah antara kedua kompartemen atau ruang utama dalam upaya untuk mempertahankan keseimbangan nilai cairan. ${ }^{4}$ Perpindahan cairan antara CIS dan CES ditentukan oleh kekuatan osmotik. ${ }^{5}$ Hilangnya cairan intraseluler ke dalam ruang yang tidak mempengaruhi keseimbangan antara cairan intraseluler dengan ekstraseluler disebut sebagai perpindahan cairan ruang ketiga. Efek dari perpindahan cairan ruang ketiga yaitu ditandai dengan pening, peningkatan frekuensi jantung, penurunan tekanan darah, penurunan tekanan intra sentral (TIS), edema, peningkatan berat badan, dan ketidakseimbangan dalam masukan dan keluaran cairan. ${ }^{4}$

Ruang ketiga memiliki dua fase berbeda, yaitu penurunan dan reabsorpsi. Pada fase penurunan, peningkatan permeabilitas kapiler menyebabkan hilangnya protein dan cairan dari ruang intravaskuler ke ruang interstitial. Fase ini berlangsung 24 sampai 72 jam setelah keadaan awal yang menyebabkan permeabilitas kapiler meningkat (misalnya, pembedahan, trauma, luka bakar, atau sepsis). Kehilangan cairan akibat diare, muntah, atau perdarahan dapat diukur, tetapi kehilangan cairan dari ketiga ruang tidak begitu mudah untuk diukur. Tanda dan gejala termasuk penambahan berat badan, penurunan output urin, dan tanda-tanda hipovolemia, seperti takikardia dan hipotensi. Selama fase reabsorpsi, jaringan mulai sembuh dan cairan diangkut kembali ke dalam ruang intravaskuler. Tanda-tanda hipovolemia, urin output meningkat, berat badan pasien stabil, dan tanda-tanda syok (jika ada) mulai membaik. ${ }^{3}$

\section{DISKUSI}

Sindrom ruang ketiga mengakibatkan cairan di dua kompertemen yang normal berpindah ke kompartemen yang tidak seharusnya. Sindrom ruang ketiga tidak terjadi begitu saja, penyebab-penyebab yang dapat mengakibatkan sindrom ruang ketiga adalah peningkatan permeabilitas kapiler, penyumbatan limfatik, dan plasma protein yang rendah. ${ }^{6}$ Ruang ketiga ini dapat dibagi menjadi bagian "anatomi" dan "non-anatomis". Cairan fisiologis yang bergeser dari vaskuler menuju ruang interstisial melintasi penghalang vaskuler utuh hanya mengandung sejumlah kecil protein. Ini tidak menyebabkan edema interstisial asalkan dapat dikelola secara kuantitatif oleh sistem limfatik. Kehilangan ruang ketiga anatomis didasarkan 
pada mekanisme ini, namun dalam kualitas patologis, yang melampaui kapasitas sistem limfatik. Ruang ketiga non-anatomis, sebaliknya, diyakini sebagai kompartemen yang terpisah dari ruang interstisial. Kehilangan terhadap kompartemen ini diasumsikan terjebak dan hilang untuk pertukaran ekstraseluler. Contoh yang dikutip untuk kehilangan ruang ketiga non-anatomik adalah akumulasi cairan pada jaringan trauma, usus, atau rongga peritoneal, namun walaupun penelitian intensif, ruang seperti itu belum pernah diidentifikasi. Cairan bergeser dari intravaskuler ke ruang interstisial. ${ }^{7}$

Pasien dengan sindrom ruang ketiga memiliki kumpulan dari gejala-gejala gangguan keseimbangan cairan, di antaranya peningkatan ketebalan perut, perkusi dull di atas perut dengan tanda penipisan vaskuler (abnormal cepat atau nadi ekstrem lambat), kadar albumin serum harus diperiksa karena kadar albumin serum rendah menyebabkan cairan berpindah keluar dari ruang vaskuler karena albumin biasanya mempertahankan tekanan osmotik koloid plasma di dalam pembuluh darah, hipovolemia, reduksi urin output, peningkatan graviti spesifik, peningkatan cepat hemoglobin dan hematokrit, takikardia, hipotensi, penurunan intensitas nadi perifer, dan lamban waktu pengisian kapiler. ${ }^{8,9}$

Dalam banyak kasus, penyebab ruang ketiga membutuhkan ketajaman dalam penegakan diagnosis, meliputi hitung darah lengkap (complete blood count/ $\mathrm{CBC}$ ). Hitung darah lengkap dapat memberikan petunjuk untuk status volume dan faktor yang berkontribusi terhadap ruang ketiga, seperti infeksi atau nekrosis. Peningkatan nilai hemoglobin dan hematokrit dapat menunjukkan hipovolemia; nilai menurun mungkin menunjukkan hipervolemia. ${ }^{3}$ Profil metabolik lengkap akan memberikan petunjuk untuk fungsi ginjal dan hati serta keseimbangan elektrolit (terutama natrium menunjukkan penurunan $<135 \mathrm{mEq} / \mathrm{L}$ ), dan tingkat protein, termasuk albumin yang menurun $<3,5 \mathrm{mEq} / \mathrm{L} .{ }^{10}$ Serum osmolalitas, ekokardiogram, yang dapat menghasilkan informasi tentang fungsi jantung dan status volume. $^{3}$

Pengobatan ruang ketiga tergantung pada penyebab, fase, dan faktor-faktor yang terlibat. Menstabilkan status hemodinamik pasien adalah prioritas pertama. Selama fase penurunan, fokus pengobatan adalah mencegah hipovolemia dan hipotensi, yang dapat menyebabkan syok dan gagal ginjal. Selama fase reabsorpsi, kita harus berfokus pada pencegahan kelebihan beban sirkulasi dan hipertensi, yang dapat menyebabkan edema paru. Untuk menstabilkan status volume pasien, diperlukan manajemen penggunaan cairan kristaloid, koloid, atau kombinasi. Kristaloid mengganti elektrolit dan mengembalikan osmolalitas serum normal; koloid menggantikan protein yang bertanggung jawab untuk menjaga koloid plasma tekanan osmotik. Kristaloid yang paling sering digunakan, dan juga 
dapat mengobati hiponatremia. Satu hal yang perlu diingat, cobalah untuk mengisi volume intravaskuler, tidak menguras ruang ketiga. ${ }^{3}$

Cairan kristaloid dapat hipotonik, isotonik, atau hipertonik. Solusi hipotonik, seperti larutan natrium klorida $0,45 \%$, tidak sesuai untuk resusitasi volume karena sangat sedikit cairan akan tetap berada di ruang intravaskuler. Solusi isotonik seperti ringer laktat dan larutan natrium klorida $0,9 \%$, yang mirip dengan plasma di tonisitas dan osmolalitas, digunakan untuk resusitasi, dengan larutan natrium klorida $0,9 \%$ lebih sering digunakan jika pasien hiponatremia. Larutan hipertonik, seperti larutan natrium klorida 3\%, mengandung sejumlah besar natrium dan telah jarang digunakan untuk resusitasi karena potensinya yang dapat menyebabkan dehidrasi seluler dan ekspansi cepat dari ruang intravaskuler. Namun, penelitian terbaru menemukan bahwa kristaloid hipertonik lebih baik dari kristaloid isotonik untuk mengurangi ruang ketiga di perut dan sindrom kompartemen perut yang sering terjadi dengan resusitasi cairan dalam jumlah besar pada pasien dengan luka bakar yang luas. Studi lain dari pasien sakit kritis menemukan bahwa meskipun volume yang lebih kecil dari larutan hipertonik diperlukan untuk resusitasi cairan, tidak ada cukup bukti untuk menentukan apakah larutan hipertonik lebih aman atau lebih efektif daripada solusi isotonik. ${ }^{3}$

Pada tahun 2004, SAFE (saline versus albumin fluid evaluation) studi dievaluasi dengan menggunakan resusitasi cairan menggunakan koloid seperti albumin, dibandingkan dengan kristaloid. Studi ini menemukan bahwa albumin tidak berhubungan dengan morbiditas dan mortalitas yang lebih tinggi pada pasien sakit kritis. Pada pasien trauma dewasa muda yang sebelumnya tanpa penyakit kardiovaskuler atau paru, resusitasi dengan albumin atau 0,9\% larutan natrium klorida mungkin tidak membuat perbedaan, kecuali yang berhubungan dengan biaya karena albumin jauh lebih mahal. Namun, pada orang dewasa yang lebih tua, pasien yang terkait dengan cedera otak traumatis, dan pasien dengan penyakit kardiovaskuler atau paru, penggunaan koloid akan menyebabkan peningkatan morbiditas dan mortalitas dibandingkan dengan penggunaan kristaloid. Saat ini, karena biaya dan potensi efek samping dari koloid, terutama jika albumin manusia digunakan, penelitian tidak mendukung penggunaan koloid. ${ }^{3}$

\section{KESIMPULAN}

Sindrom ruang ketiga adalah ketika cairan tubuh yang berasal dari kompartemen normal berpindah ke kompartemen yang tidak seharusnya seperti pada perikardium, peritoneum, dan pleura. Sindrom ruang ketiga bermanifestasi hipovolemia, reduksi urin output, peningkatan dari graviti spesifik, peningkatan hemoglobin dan hematokrit, takikardia, 
hipotensi, penurunan intensitas nadi perifer, dan lamban waktu pengisian kapiler. Dari berbagai gejala dan tanda yang timbul pada sindrom tersebut dapat ditegakkan dengan pemeriksaan penunjang. Pemeriksaan penunjang yang dapat dilakukan adalah menghitung sel darah lengkap, profil metabolik lengkap, serum osmolalitas, dan ekokardiogram. Sindrom ruang ketiga dapat diberi tatalaksana sesuai dengan etiologi, patofisiologi, dan faktor risikonya. Hal yang paling penting dalam tatalaksana sindrom ruang ketiga adalah stabilisasi hemodinamik pasien.

\section{DAFTAR PUSTAKA}

1. Sherwood, L, Fisiologi Manusia: Dari Sel ke Sistem Edisi 6. Buku Kedokteran EGC, Jakarta, 2012.

2. Ganong, WF, Buku Ajar Fisiologi Kedokteran Edisi 20. Buku Kedokteran EGC, Jakarta, 2003.

3. Holcomb, SS, Topics In Progressive Care: Third-spacing: When body fluid shifts, 2009, Diunduh: 30 April 2019 dari

$<$ http://www.nursingcenter.com/journalarticle?Article ID=859815>

4. Wahyudi, A, Asuhan Keperawatan Pada Gangguan Keseimbangan Cairan dan Elektrolit, 2016, Diunduh: 30 April 2019 dari

$<$ https://www.researchgate.net/profile/Andri_Wahyudi/publication/311455903 Ilmu_Ke perawatan Dasar/links/5847de1908aeda69682582be/Ilmu-Keperawatan-Dasar>

5. Price, SA, Lorraine, MW, Patofisiologi: Konsep Klinis Proses-Proses Penyakit Edisi 6 Volume 1, Buku Kedoktran EGC, Jakarta, 2005.

6. White, A, The Renal System, Cleveland Clinic, 2013, Diunduh: 30 April 2019 dari $<$ https://my.clevelandclinic.org/ccf/media/files/nursing/2013-nursing-ccrn-pccnhandouts/2013-white-renal-system.pdf $>$

7. Strunden, MS., et al., Perioperative fluid and volume management: Physiological basis, tools and strategies, Annals of Intensive Care, German, 2011.

8. Chintamani, Lewis's Medical Surgical Nursing, Elsevier, India, 2011, Diunduh: 30 April 2019 dari

$<$ https://books.google.co.id/books?id=1dyS2MKkB7AC\&pg=PA297\&lpg=PA297\&dq=th ird + space + syndrome \&source $=$ bl\&ots $=9$ WUkMO-

HoM\&sig=KgbwCu4iOb530mclYfLgcgQYjz8\&hl=ban\&sa=X\&ved=0ahUKEwj98JLXp c7WAhVKto8KHfy0ChQQ6AEIYTAN\#v=onepage \&q=third $\% 20$ space $\% 20$ syndrome \&f $=$ false>

9. Wise, BV., et al., Nursing Care of the General Pediatric Surgical Patient, United State, 2000, Diunduh: 30 April 2019 dari

$<$ https://books.google.co.id/books?id=n3JJO2FfL80C\&pg=PA30\&lpg=PA30\&dq=third + spacing + signs + and + symptoms \&source $=$ bl\&ots $=$ FoNtG43UUH\&sig=ghqld8fOrg4mPjW qy5GKpwDm5eQ\&hl=ban\&sa=X\&ved=0ahUKEwic48 k9s7WAhUEqI8KHaggBScQ6 AEIWDAJ $\# \mathrm{v}=$ onepage $\& \mathrm{q}=$ third $\% 20$ spacing $\% 20$ signs $\% 20$ and $\% 20$ symptoms $\& \mathrm{f}=$ false $>$

10. Agustin, L, Cairan dan Elektrolit, 2014, Diunduh: 30 April 2019 dari

$<$ https://www.academia.edu/13065339/cairan_dan_elektrolit $>$ 